\title{
Quality Assurance Issues in the Teaching and Learning of Physics in Secondary Schools.
}

\author{
Agommuoh, P. C. (Dr.) \\ College Of Agricultural And Science Education, Department Of Science Education, Michael Okpara University \\ Of Agriculture, Umudike, Umuahia, Abia State Nigeria.
}

\begin{abstract}
This study which employed a descriptive survey design aimed at investigating quality assurance issues in the teaching and learning of physics in secondary schools in Umuahia Education zone of Abia State. A sample of 79 (seventy-nine) physics teachers was purposively selected. All the physics teachers in all the secondary schools in Umuahia North Local Government Area were used for the study. The research instrument used for data collection was a researchers' developed structured questionnaire of the Likert type. These instruments were faced and content validated by experts of Measurement and Evaluation. The reliability of the instrument was obtained as $r=0.87$. Two research questions and one hypothesis tested at 0.05 level of significance guided the study. Mean was used to answer the research questions while the hypothesis was tested with chi-square statistics. The study among other things revealed that well equipped laboratories, qualified physics teachers, hands-on activity methods of teaching, constant monitoring of students progress and proper record keeping of students' attendance to class and class work contribute to quality assurance to the teaching and learning of physics in our secondary schools. The study therefore recommended that there is need for proper equipment of physics laboratories; workshops and training should be provided to equip the teachers on how to develop reliable and quality test items for teachers and that proper keeping of school attendance registers, school diaries and other records are of paramount importance.
\end{abstract}

Keywords: Education, Physics, Physics Education and Quality assurance.

\section{Introduction}

Education has been described as the bedrock of every society and tool for nation building. This is to say that the development of any modern nation has been found to be linked to the quality of its education system. Adegbesan (2011). opined that for quality education to be achieved in a nation, the principal actors of learning which are the teachers, learners and the environment must be cooperatively organized. This means that the teacher must be adequate in quality and quantity, the student must be well trained and facilities must be provided. Quality assurance ensures that input, processes and output of the education system are geared towards meeting set standards to bring about improvement in teaching and learning. Education today must have the effect of making it possible for a country to have a steady supply of highly creative citizens who help to keep improving the living conditions and of the general citizenry and to solve the existential problems that are thrown up from time to time. Yoloye (2005) agrees that quality must characterize education and every stage and the real problem that government have to face is deciding the mix of levels, of how many must go beyond the basic education and how many must have higher education?

Quality assurance is a mechanism used to evaluate the efficiency and appropriateness in teaching and learning in secondary schools so as to ensure the delivery of high quality education (Sofowara, 2010). Quality assurance is really the best way to begin to turn around the present state of the Nigerian education system to serve as a change agent to meet local needs and for global competitiveness after several quantities of mass failure and half baked products from our various educational institutions. Sofowara (2010) opined that quality assurance is a holistic method of identifying and resolving problem within the educational system in order to ensure continuous quality improvement. It can also be described as means of disseminating information regarding the quality of secondary education. According to Bateman (2006), quality assurance includes defined standards of achievement, documented procedures for all identified processes; establish ways of responding to issues and clear accountability for outcomes. Arikenuyo (2004) views quality in education to be judged by both its ability to enable the students perform well in standard examination and relevance to the needs of the students, community and the society as a whole. Quality assurance in education can also be defined as an all encompassing concept which includes all inputs, process and actions through which the quality of education is developed, improved and maintained (Obioma, 2012). This implies that quality assurance involves all the processes that contribute to the success of the end-products of the school quality which serves as determination of graduation based on standard of excellence beneath which a mark of inferiority is imposed or adduced and above which grades of superiority are defined (Arikenuyo, 2004). Ajayi and Adegbesan (2007) argued that quality assurance is related to accountability both of which are concerned with maximizing the effectiveness and 
efficiency of educational system and services in relation to their contexts of their mission and their slated objectives. Buttressing this Ehindero (2004) emphasized that quality assurance focused on:

i. Learners entry behavior, characteristics and attributes including some demography factors that can inhibit or facilitate their learning.

ii. The teacher entry qualification, values, pedagogic skills, professional preparedness, subject background, philosophical orientation.

iii. The teaching/learning processes including the structure of the curriculum and learning environment.

iv. The outcomes which are defined for different levels in terms of knowledge, skills and altitudes including appropriate and relevant instruments to access these objectives contributing, Fadokum (2005) sums the defaulting objectives, actions and procedures that through their existence and use and together with quality control activities ensure that appropriate academic standards are being maintained and enhanced in and by each programme.

According to National Educational Quality Assurance Policy, Nigeria is concerned with eight

(8) components of quality assurance standards that are itemized as:

- Learner achievement and standard

- Learners welfare and participation

- Care guidance and support

- Leadership and management

- School community relationship

- Learning environment

- Teaching and learning

- Curriculum

The importance of consistence and continuous quality assurance in secondary education are many. These benefits associated with consistent quality assurance and continuous quality improvement measures in our secondary education include:-

$>$ The establishment of establish high standard academic excellence which will go a long way to enhance schools reputation and images.

$>$ Improved communication across the school system.

$>$ Improvement of outcome so that the policies and procedures are constantly revisited through analysis and the delivery of teaching and learning.

$>$ Identification of systems strengths and weaknesses.

$>$ Determination of the programme effectiveness and tracking of its integrity and

$>$ Increase in capacity to secure funding and refinement service delivery. Quality assurance connects the goals to which all secondary schools students, teachers, staff and school leaders must achieve.

Physics which is one of the sciences is the study of matter, energy and their interactions. Physics is an international enterprise which plays a key role in the future progress of humankind. The fact that the quality of physics education helps in the technological potential of a country than the size of its population cannot be over emphasized. This implies that our country cannot develop technologically if the quality of the teaching and learning of physics in our secondary schools is not assured.

According to Obioma (2012), the quality of teaching and learning is determined by the quality of:

* Instructional materials

* Readiness of learners

* Child-friendly school environment

* Methodology and the teaching/learning approaches

* Capacity and professional development of teachers

* Well-spaced and ventilated classrooms

* Socio economic status of learners and

* Synchronous use of daily lesson play, derived from well organized daily work plans and services of work that meet minimum standards as well as appropriate content standards of the curricula specifications, at all level of education.

Physics education emphasizes the delivery of physics knowledge and skills, the quality assurance of physics education is often focused on how well physics learning and teaching are organized to deliver the necessary knowledge and skills to students; how well the delivery of physics knowledge and skills to students can be ensured through the improvement of teaching and learning; how well teachers' physics teaching can be improved in a given time period and how well students can arrive at a given standard in physics examination. Hence the need to investigate quality assurance issues in the teaching and learning of physics in our secondary schools. 


\section{Research Questions}

The following research questions guided the study

1. What are the mean scores of physics teachers' perception of quality assurance issues in teaching/learning in secondary schools.

2. What are the mean scores of male and female physics teachers' perception of quality assurance issues in teaching and learning in secondary schools

\section{Hypothesis}

The following null hypothesis tested at 0.05 level of significance guided the study

There is no significant difference between male and female physics teachers' perception of quality assurance issues in teaching/learning in secondary schools

\section{Methodology}

Descriptive survey design was adopted in this study. A sample of 79 (seventy-nine) physics teachers was purposively selected. The instrument for data collection was a researcher's developed structured questionnaire of the Likert type on physics teachers' assessment of steps taken to ensure quality assurance in the teaching/learning of physics in secondary schools. The responses are Strongly Agree (SA), Agree (A), Disagree (D) and Strongly Disagree (SD) weighted 4,3,2,1 respectively. It is a ten-item questionnaire that is made up of issues to consider in order to bring about quality assurance in the teaching/learning of physics in the secondary schools. The instrument was face and content validated by one expert in test and measurement and two others who are physics education specialist. The reliability index was determined by cronbach alpha and found to be 0.87 . The questionnaire was distributed by the researcher and collected back and so percentage return was $100 \%$. The research questions were analyzed using means while the hypothesis was tested using chi-square statistic at 0.05 level of significance.

\section{Results}

The findings got from the study are presented in tables 1 and 2 below.

Table 1:

Mean scores of male and female teacher' perception of factors that can contribute to the attainment of quality assurance in the teaching and learning of physics.

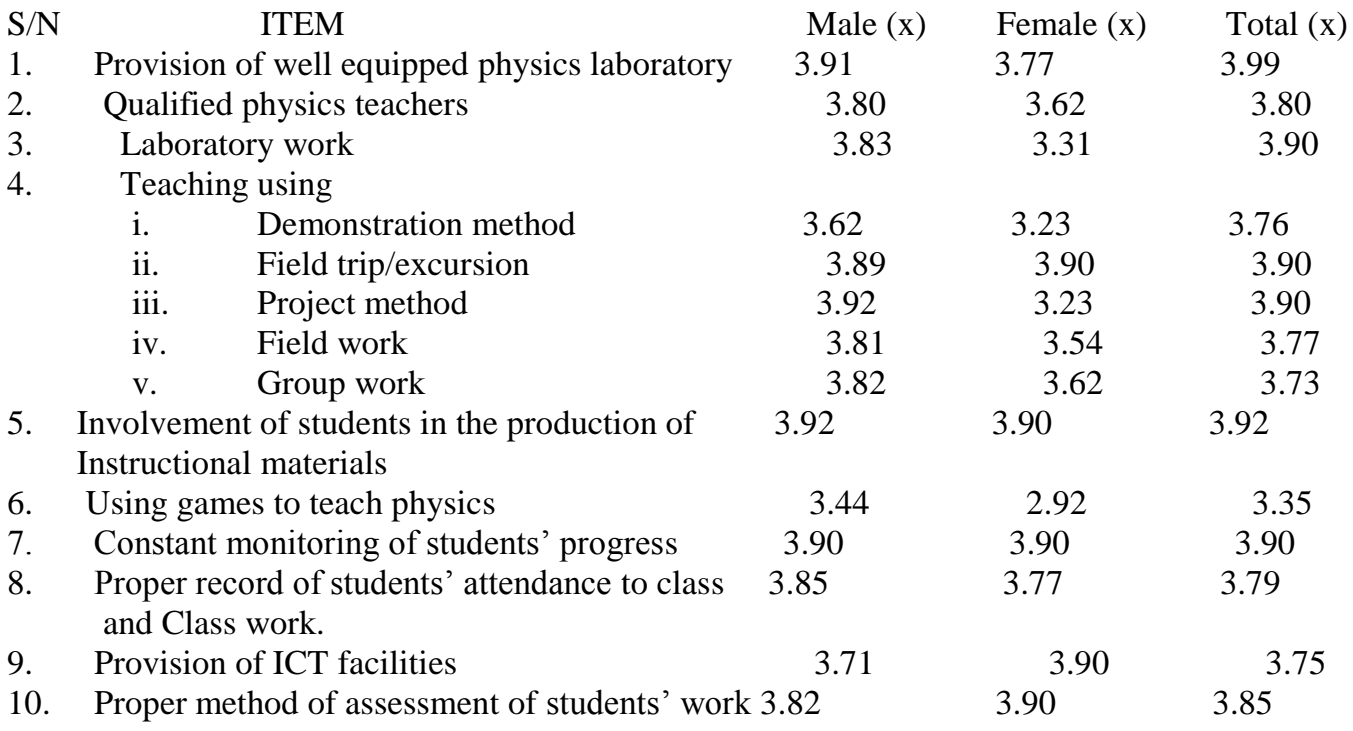

Result in table 1 above clearly showed that all the items had mean scores that are greater than 2.5 which is the mean score value of the four point scale used. The physics teachers all agreed that these factors can contribute to the attainment of quality assurance in the teaching and learning of physics in our secondary schools. The table also showed that the mean scores of both male and female teachers are above 2.5. 
Table 2:

$\mathrm{X}^{2}$ values of male and female teachers perception of factors that can contribute to the attainment of quality assurance in the teaching and learning of physics.

$\begin{array}{lcccccc} & & \text { SA } & \text { A } & \text { D } & \text { SD } & \text { TOTAL } \\ \text { MALE } & 66 & 793 & 90 & 32 & 9 & 924 \\ & & (\mathbf{7 8 6}) & (\mathbf{9 5}) & (\mathbf{3 4}) & \mathbf{( 9 )} & \\ \text { FEMALE } & 13 & \mathbf{1 4 7} & \mathbf{2 3} & \mathbf{9} & \mathbf{2} & 181 \\ & & (\mathbf{1 5 4}) & (\mathbf{1 9 )} & \mathbf{( 7 )} & (\mathbf{2}) & \\ \text { TOTAL } & \mathbf{7 9} & \mathbf{9 4 0} & \mathbf{1 1 3} & \mathbf{4 1} & \mathbf{1 1} & \mathbf{1 1 0 5}\end{array}$

Table 2 above showed that the calculated $\mathrm{X}^{2}$ value 2.13 is less than the critical/ table $\mathrm{X}^{2}$ value of 7.815 . This implies that the null hypothesis is accepted which means there is no significant difference between male and female physics teachers' perception of quality assurance issues in teaching/learning of physics in secondary schools.

\section{Discussion}

From table 1, the mean scores of all the listed items are greater than 2.5 which is the mean score value of the four point scale used. The implication of this is that all the teachers, both males and females agreed that the listed items are measures needed to be taken to ensure quality assurance in the teaching/ learning of physics in our secondary schools.

This can be said to be in agreement with Ojedele (2007) who opined that for quality assurance to be ensured, there is the need to examine the qualification of teachers, the adequacy of the curriculum, availability of equipment in the required number as well as the proper use of the processes involved in the various skills to ensure that the finished products are of high standard. The result is also in line with the fact that the quality of teaching and learning is determined by the quality of instructional materials, methodology and / or teachinglearning approaches, maintenance of records, as well as ensuring adequate preparation and delivery of lessons by teachers with quality learning inputs, processes and outputs / outcomes to be efficiently documented ( Obioma, 2012). This also means that these factors if attained according to Adegbesan (2011) will have the effect of making it possible for our country to have a steady supply of highly creative citizens who help to keep improving the living conditions of the general citizenry, and to solve existential problems that are thrown up from time to time.

From table 2, it is observable that the null hypothesis was accepted meaning that gender played no role. The implication of this is that both male and female teachers see those factors as things that must be done to ensure quality assurance in the teaching and learning of physics in our secondary schools.

\section{Conclusion/Recomendation}

For our secondary school physics education to be able to meet global competitiveness, quality assurance in the teaching and learning of the subject should be assured. The following recommendations are therefore made;

1. The various school managers should ensure that qualified physics teachers are employed to teach the subject.

2. Well equipped physics laboratories should be provided in all our secondary schools.

3. There should be constant monitoring of physics teaching to ensure that activity and learner centered methods that facilitate science learning are used.

4. There should also constant monitoring of students' progress, proper record keeping of students' attendance to class/ class work and proper method of assessment of students' work.

As a way forward, secondary school physics education must engage in quality assurance activities to ensure that global best practices are imbibed and also their services and products remain globally competitive.

\section{References}

[1]. S. O. Adegbesan, Establishing quality assurance in Nigeria education system: Implication for educational managers. Educational Research and Reviews 2011, Vol. 6(2) pp. 147-151. Available online at http:// www.academicjournals.org/ERR

[2]. E.A. Yoloye . The relevance of Universal Basic Education in the development of primary education system in Nigeria. In: Adepoju, T. L. (Ed) Planning and implementation of Universal Basic Education in Nigeria. Ibadan.2005 Educational industries Nig. Limited.

[3]. O.A.Sofowara Improving the standard and quality of primary education in Nigeria: A case study of Oyo and Ogun States. International Journal for Cross- Disciplinary subjects in Education 2010, Volume 1, Issue 3. 
[4]. P. Bateman. Quality Assurance mechanisms open, distance e-learning (O- Del). A lead paper presented at a workshop organized by African Virtual University, Kenya in collaboration with Carnegie Corporation and Information Technology and Communication Unit. Obafemi Awolowo University, Ile-Ife.2006.

[5]. M. O. 'Arikewuyo,. Effective funding and quality assurance in the Nigeria education system. A paper presented at the $1^{\text {st }}$ National Conference of the Institute of Education, Olabisi Onabanjo University, Ago-Iwoye 2004, Jan. 12-15.

[6]. G. Obioma (2012). Repositioning Academic researchers in the $21^{\text {st }}$ Century Nigerian University for sustainable National Development: Issues, challenges and opportunities. A paper presented at the conference of 2012 committee of Directors of Universities Academic Planning of Nigerian Universities (CODAPNU) $2^{\text {nd }}$ October, 2012 at NUC, Abuja.

[7]. T. Ajayi and S. O. Adegbesan. Quality assurance in the teaching profession. Paper presented at the forum on emerging issues in teaching professionalism in Nigeria (14-16 March) 2007,Akure, Ondo State.

[8]. S. Ehindero. Accountability and quality assurance in Nigerian Institute of Education, Olabisi Onanbanjo University, Ago-Iwoye. 2004, (Jan $\left.12^{\text {th }}-15^{\text {th }}\right)$

[9]. J.B.Fadokun (2005). Educational assessment and quality assurance implication for principal instructional leadership roles. Paper presented at the $31^{\text {st }}$ Annual Conference of International Association for Educational Assessment 2005, 4-9 September, Abuja.

[10]. P.K. Ojedele. Vocational and technical education in Nigeria. Issues and challenges. A paper presented at the international conference of the Nigerian association for educational management administration and planning (NAEP) held at University of Lagos 2007, (24-27 Sept.) 